\title{
Mortality and immune challenge of a native isolate of Beauveria bassina against the larvae of Glyphodes pyloalis Walker (Lepidoptera: Pyralidae)
}

\author{
Sarah Aghaee Pour ${ }^{1}$, Arash Zibaee ${ }^{1 *}$ (D) Maryam Gohar Rostami ${ }^{1}$, Hassan Hoda ${ }^{2}$ and Morteza Shahriari ${ }^{1}$
}

\begin{abstract}
Background: Entomopathogenic fungi (EPF) attack a wide range of insects. They are considered environmental friendly alternatives to synthetic insecticides for pest control. In the present study, virulence of a native isolate of the EPF, Beauveria bassiana Vuillemin (Hypocreales: Cordycipitaceae) was evaluated against the least mulberry pyralid, Glyphodes pyloalis Walker (Lepidoptera: Crambidae), through bioassay, pathogenic pathways, and immune responses.

Results: The values of $2.6 \times 10^{4}$ conidia/ml and 3.54 days were determined as the median lethal concentration $\left(\mathrm{LC}_{50}\right)$ and median lethal concentration ( $\left.L T_{50}\right)$ of $\mathrm{AM}-118$ against the 4th instar larvae of $G$. pyloalis, respectively. The activities of proteases and chitinases in the culture medium containing the larval cuticle were higher than the control medium. Moreover, the total and the differential hemocyte counts of the larvae were significantly changed after injection with AM-118 spores. The highest numbers of total hemocytes and granulocytes were obtained 3 and $6 \mathrm{~h}$ post-injection, while the highest numbers of plasmatocytes and nodules were observed $6 \mathrm{~h}$ post-injection. The highest activity of phenoloxidase was determined $12 \mathrm{~h}$ post-injection by AM-118 spores.
\end{abstract}

Conclusions: The findings imply on virulence of the AM-118 isolate against the larvae of G. pyoalis although immune responses were triggered by the spores.

Keywords: Glyphodes pyloalis, Beauveria bassiana, Immunity, Mycoinsecticides, Virulence

\section{Background}

The lesser mulberry pyralid, Glyphodes pyloalis Walker (Lepidoptera: Pyralidae), is an important pest with annually sever damages on mulberry. The larvae intensively feed on leaves, fold them, and retain the black feces to lose quality of the leaves for silkworm rearing (Khosravi and Jalali Sendi 2010). Another important case is the capability of transmitting pathogenic diseases to silkworm (Watanabe et al. 1988). The main control measure is to spray chemical insecticides although the excessive

\footnotetext{
* Correspondence: arash.zibaee@gmx.com; arash.zibaee@guilan.ac.ir 'Department of Plant Protection, Faculty of Agricultural Sciences, University of Guilan, Box 41635-1314, Rasht, Iran

Full list of author information is available at the end of the article
}

use of these pesticides has resulted in adversely severe effects on non-target organisms mainly silkworm (Yazdani et al. 2013). Therefore, considering eco-friendly measures like natural enemies, predators, parasitoids, or entomopathogens seems to be necessary.

Several researches have studied the effects of entomopathogenic fungi (EPF) especially, Beauveria bassiana Vuillemin (Hypocreales: Cordycipitaceae) isolates against many lepidopteran insect pests. EPF not only have significant virulence against insects but they also play important roles in physiological functions by inactivation of enzymes or triggering some processes (Ramzi and Zibaee 2014; Baja et al. 2020). In infection pathway, conidia should be connected to the cuticle of host, 
germinated via different layers and reproduced after reaching the hemocoel. Then, produced blastospores led to kill the insect hosts by production of secondary metabolites and consumption of nourishing resources in host bodies (Brownbridge et al. 2001).

Before any suggestion for field application, it is necessary to understand the infection mechanism of EPF on the specific insect; therefore, the aims of the present research were to (a) bioassay the virulence of a native isolate of B. bassiana against the larvae of G. pyloalis, (b) evaluate the production of extracellular enzymes in presence of the host cuticle to find correlation between secretion of these compounds and virulence, and (c) evaluate the immune responses in the hemolymph of the larvae encountering the spores of B. bassiana.

\section{Methods}

\section{Insects}

Larvae of G. pyloalis were collected from infested mulberry plantation of Rasht, northern Iran $\left(37^{\circ} 19^{\prime} \mathrm{N}, 49^{\circ}\right.$ $\left.37^{\prime} \mathrm{E} ;-9 \mathrm{~m}\right)$. Rearing of insect was carried out in a growth chamber at $24 \pm 2{ }^{\circ} \mathrm{C}, 70 \pm 5 \%$ R.H., and 16:8 (L: D) $h$ of photoperiod on fresh mulberry leaves (Yazdani et al. 2013). Adult moths were placed in transparent plastic containers $\left(20 \times 12 \times 12 \mathrm{~cm}^{3}\right)$ and provided with fresh mulberry leaves for egg-laying and a cotton wool soaked in $10 \%$ honey for adult feeding. The containers were cleaned daily and fresh leaves were provided for the larvae.

\section{Beauveria bassiana fungal culture}

AM-118 isolate of B. bassiana was cultured on Potato Dextrose Agar (PDA) and kept at $25 \pm 1{ }^{\circ} \mathrm{C}$ for 21 days. Then, the conidia were washed off by a $0.01 \%$ aqueous solution of Tween 80 to prepare a stock sample of fungal conidia. The isolate was collected from a rice field at Amol $\left(2625^{\prime} \mathrm{N}, 5221^{\prime} \mathrm{E} ; 17 \mathrm{~m}\right)$ and registered in herbarium of mycology.

\section{Bioassay}

The serial concentrations of $10^{3}, 10^{4}, 10^{5}, 10^{6}$, and $10^{7}$ conidia/ml of AM-118 were prepared in sterile distilled water containing Tween 80 (0.02\%); then, the early 4th instar larvae of G. pyloalis were randomly selected and separately dipped in each concentration for $5 \mathrm{~s}$. The control larvae were dipped in aqueous solution of Tween $80(0.02 \%)$ alone. After treatment, the larvae were placed on filter paper (Whatman No. 1), provided with fresh leaves, and kept at the rearing conditions. The bioassay was done in 3 replicates, containing 10 larvae/ replication. Mortality was recorded after 7 days and $\mathrm{LC}_{50}$ was determined using POLO-plus software. For estimation of $\mathrm{LT}_{50}$, the mortality was recorded until death of all larvae at the highest conidia concentration.
Liquid culture for enzyme production

A liquid medium, including $\mathrm{KH}_{2} \mathrm{PO}_{4}, 0.02 \% ; \mathrm{CaCl}_{2}$, 0.01\%; $\mathrm{MgSO}_{4}, 0.01 \% ; \mathrm{Na}_{2} \mathrm{HPO}_{4}, 0.02 \% ; \mathrm{ZnCl}_{2}, 0.01 \%$; and yeast extract, $0.01 \%$, was used for enzymatic production of AM-118. Culture flasks were inoculated with a concentration of $10^{8}$ conidia/ml and $5 \%$ (weight) of G. pyloalis larval cuticle and incubated for 8 days at $25 \pm 1$ ${ }^{\circ} \mathrm{C}$ on a rotatory shaker $(70 \mathrm{rev} / \mathrm{min}$ ) (Zibaee and Bandani 2009). In control flasks, starch and potato extract were added instead of larval cuticle.

\section{Sample preparations for enzymatic assays}

Eight days post-incubation, the mixture was harvested by centrifugation at $10,000 \times g$ and $4{ }^{\circ} \mathrm{C}$ for $30 \mathrm{~min}$ and washed in ice-cold Tris- $\mathrm{HCl}(25 \mathrm{mM}, \mathrm{pH} 8)$. Weighed mycelia were ground to a fine powder and suspended in distilled water. Then, the samples were homogenized and centrifuged at $20,000 \times g$ and $4{ }^{\circ} \mathrm{C}$ for $30 \mathrm{~min}$ to gain the supernatant for the enzymatic assays (Ramzi and Zibaee 2014).

\section{Assay of proteases}

Activities of subtilisin-like (Pr1) and trypsin-like (Pr2) as the 2 main fungal proteases were evaluated by $30 \mu \mathrm{l}$ of succinyl-(alanine) 2-prolinephenylalanine-p-nitroanilide for $\operatorname{Pr} 1$ and benzoylphenylalanine-valine-arginine- $p$ nitroanilide for Pr2 in $100 \mu \mathrm{l}$ of Tris- $\mathrm{HCl}$ buffer $(20$ $\mathrm{mM}, \mathrm{pH}$ 8). Afterward, $20 \mu \mathrm{l}$ of the enzyme solution was added to the mixture and incubated at $25{ }^{\circ} \mathrm{C}$ for $10 \mathrm{~min}$. Then, $100 \mu \mathrm{l}$ of trichloroacetic acid (TCA, 30\%) was added and the absorbance was recorded at $405 \mathrm{~nm}$ (Zibaee and Bandani 2009).

\section{Endo-chitinase assay}

A reaction mixture, containing $50 \mu \mathrm{l}$ of $0.5 \%$ colloidal chitin as substrate, $20 \mu \mathrm{l}$ of enzyme sample, and $100 \mu \mathrm{l}$ of Tris- $\mathrm{HCl}$ buffer $(20 \mathrm{mM}, \mathrm{pH} 7)$, was prepared to assay endo-chitinase activity. The tubes containing reaction mixture were incubated in a water bath $\left(30^{\circ} \mathrm{C}\right)$ for $60 \mathrm{~min}$. Then, $100 \mu \mathrm{l}$ of DNS (dinitrosalicylic acid) was added and the incubation was prolonged for $10 \mathrm{~min}$ at boiling water before reading the absorbance at $545 \mathrm{~nm}$ (Miller 1959).

\section{Exo-chitinase assay}

Assay of exo-chitinase activity was carried out, using 200 $\mu \mathrm{l}$ of $p$-nitrophenyl- $N$-acetyl- $\beta$-D-glucosaminide (pNPg) solution $(1 \mathrm{mg}$ pNPg per $\mathrm{ml}$ of distilled water) as substrate, $500 \mu \mathrm{l}$ of Tris- $\mathrm{HCl}(25 \mathrm{mM}, \mathrm{pH} 7)$, and $25 \mu \mathrm{l}$ of culture filtrate. The mixture was incubated for $20 \mathrm{~h}$ at $30{ }^{\circ} \mathrm{C}$, centrifuged at $20,000 \times g$ at $4{ }^{\circ} \mathrm{C}$, and then, supernatant was added to $200 \mu \mathrm{l}$ of sodium tetraborate- $\mathrm{NaOH}$ buffer (125 mM, pH 10) prior to reading the absorbance 
at $400 \mathrm{~nm}$. The extinction coefficient of $18.5 \mathrm{mM}^{-1}$ $\mathrm{cm}^{-1}$ was calculated.

\section{Protein assay}

The method of Lowry et al. (1951) was used to measure the amount of protein in the enzymatic preparations. Twenty microliters of the enzyme sample was added into $100 \mu \mathrm{l}$ of reagent (Ziest Chem. Co., Tehran-Iran) and incubated for 30 min before reading the absorbance at $545 \mathrm{~nm}$.

\section{Hemolymph collection and hemocyte counts}

Fourth instar larvae were injected in the latest segment of thorax by $1 \mu \mathrm{l}$ of a soluble Tween 80 containing $\mathrm{LC}_{50}$ concentration of $B$. bassiana. Then, larval hemolymph was collected at intervals of $1,3,6,12$, and $24 \mathrm{~h}$ after injection. Control larvae remained intact, while other larvae were injected by Tween 80 solution. Samples of hemolymph were bled into ice cold anticoagulant buffer in a ratio of 1-3 (0.01 $\mathrm{M}$ ethylenediamine tetraacetic acid, $0.1 \mathrm{M}$ glucose, $0.062 \mathrm{M} \mathrm{NaCl}, 0.026 \mathrm{M}$ citric acid, $\mathrm{pH}$ 4.6) (Azambuja et al. 1991). Number of total hemocyte, granulocyte, plasmatocyte, and nodules were counted, using a Neubauer hemocytometer (Chemkind Co. China). For each treatment, 10 larvae were used and the experiment had 3 replicates.

\section{Assay of phenoloxidase activity}

The activity of phenoloxidase (PO) was assayed according to the procedure described by Wilson et al. (2002). Briefly, $10 \mu \mathrm{l}$ of hemolymph was added into an Eppendorf tube $(1.5 \mathrm{ml})$, centrifuged at $2000 \times g$ and $4{ }^{\circ} \mathrm{C}$ for 15 min. Supernatant was removed and $100 \mu \mathrm{l}$ of ice-cold phosphate-buffered saline $(20 \mathrm{mM}, \mathrm{pH}$ 7) was added to the pellets. To determine PO activity, samples were poured into each well of a plate containing $20 \mu \mathrm{l}$ of 10 $\mathrm{mM}$ 3,4-dihydroxyphenylalanine (L-dopa). After $5 \mathrm{~min}$ of incubation at room temperature, the absorbance was recorded at $492 \mathrm{~nm}$.

\section{Statistical analysis}

Probit analysis was performed to determine $\mathrm{LC}_{50}$ and $\mathrm{LT}_{50}$ values at the corresponding 95\% confidence interval (CI) values by using POLO-Plus software.
Biochemical data were compared by one-way analysis of variance (ANOVA), followed by $t$ test and Tukey's test, where applicable. Differences between control and treatments were statistically analyzed at a probability less than $5 \%$ and marked by different letters.

Also, the extinction coefficient of $18.5 \mathrm{mM}^{-1} \mathrm{~cm}^{-1}$ was considered for activity calculation based on the following formula:

Volume activity $(\mathrm{U} / \mathrm{ml})=\left[\Delta \mathrm{OD}(\mathrm{OD}\right.$ test - OD blank $\left.) \times V_{\mathrm{t}} \times \mathrm{df}\right]$

$$
/\left(18.5 \times t \times 1.0 \times V_{\mathrm{s}}\right)
$$

where $V_{\mathrm{t}}=$ total volume; $V_{\mathrm{s}}=$ sample volume; $18.5=$ millimolar extinction coefficient of $p$-nitrophenol under the assay condition; $1.0=$ light path length $(\mathrm{cm}) ; t=$ reaction time; and $\mathrm{df}=$ dilution factor (Miller 1959).

\section{Results}

Results of the Am-118 bioassay against the 4th instar larvae of G. pyloalis are presented in Tables 1 and 2 . AM-118 showed a virulence against the larvae at different concentrations, and significant positive correlations among increasing concentrations of AM-118 and the larval mortality (Table 1 ).

The $\mathrm{LC}_{50}$ value of AM-118 was obtained as $2.6 \times 10^{4}$ $\left(7.8 \times 10^{3}-6.9 \times 10^{4}\right)$ spore $/ \mathrm{ml}$ (Table 1) and the $\mathrm{LT}_{50}$ value was calculated as 3.54 (2.99-4.08) days (Table 2). The activities of Pr1 and Pr2 significantly increased in the samples containing larval cuticle than in the control (Fig. 1). Similarly, high activities of endo- and exochitinase were observed in the cuticle treatment compared to control (Fig. 2).

Total number of hemocytes, number of granulocytes, and of plasmatocytes in G. pyloalis larvae demonstrated significant changes after AM-118 spore injection (Fig. 3). The total number of hemocytes increased in the larvae exposed to B. bassiana conidia in comparison to control and Tween 80 at all-time intervals. The highest number of total hemocyte was observed 3 and $6 \mathrm{~h}$ post-injection similar to granulocytes (Fig. 3). Also, injection of the spores led to the highest numbers of plasmatocytes at all-time intervals (Fig.3).

Table $1 \mathrm{LC}_{50}$ value (conidia/ml) of Beauveria bassiana against the 4th instar larvae of Glyphodes pyloalis

\begin{tabular}{llllll}
\hline Treatment & Concentrations (spore/ml) & $\begin{array}{l}\text { Mortality } \\
(\mathbf{\%}) \pm \mathbf{S E}\end{array}$ & LC $_{\mathbf{5 0}}$ (spore/ml) (95\% CL) & $X^{\mathbf{2}}$ (df) & Slope \pm SE \\
\hline Beauveria bassiana & $10^{3}$ & $23.33 \pm 3.3$ & $2.6 \times 10^{4}\left(7.8 \times 10^{3}-6.9 \times 10^{4}\right)$ & $0.433(3)$ & $0.52 \pm 0.0088$ \\
& $10^{4}$ & $40 \pm 5.7$ & & \\
& $10^{5}$ & $60 \pm 5.7$ & & \\
& $10^{6}$ & $76.66 \pm 3.3$ & & \\
& $10^{7}$ & $93.33 \pm 3.3$ & & \\
& & & &
\end{tabular}


Table $2 \mathrm{LT}_{50}$ value (days) of Beauveria bassiana against the 4th instar larvae of Glyphodes pyloalis

\begin{tabular}{llllll}
\hline Treatment & Days & $\begin{array}{l}\text { Mortality } \\
(\%) \pm \mathbf{S E}\end{array}$ & $\mathbf{L T}_{\mathbf{5 0}}$ (day) (95\% CL) & $\boldsymbol{x}^{\mathbf{2}}$ (df) & Slope $\pm \mathbf{S E}$ \\
\hline Beauveria bassiana & 1 & $3.33 \pm 0.33$ & $3.54(2.99-4.08)$ days & $6.655(6)$ & \\
2 & $16.66 \pm 0.33$ & & \\
3 & $40 \pm 0.57$ & & \\
4 & $50 \pm 0.57$ & \\
5 & $63.33 \pm 0.33$ & \\
6 & $80 \pm 0.57$ & & \\
7 & $93.3 \pm 0.66$ & & \\
8 & $100 \pm 1.15$ &
\end{tabular}

Note: Calculation was carried out by POLO-Plus software

Injection of larvae with $B$. bassiana spores caused the highest number of nodules $6 \mathrm{~h}$ post-injection but control and tween 80 larvae showed no nodules (Fig. 4). The activity of PO statistically increased in the larvae injected by AM-118 spores at all-time intervals. The highest PO activity was found 12 and
$6 \mathrm{~h}$ post-injection by AM-118 spores, respectively (Fig. 4).

\section{Discussion}

Obtained results showed the virulence of B. bassiana on the 4th instar larvae of G. pyloalis and the induction of

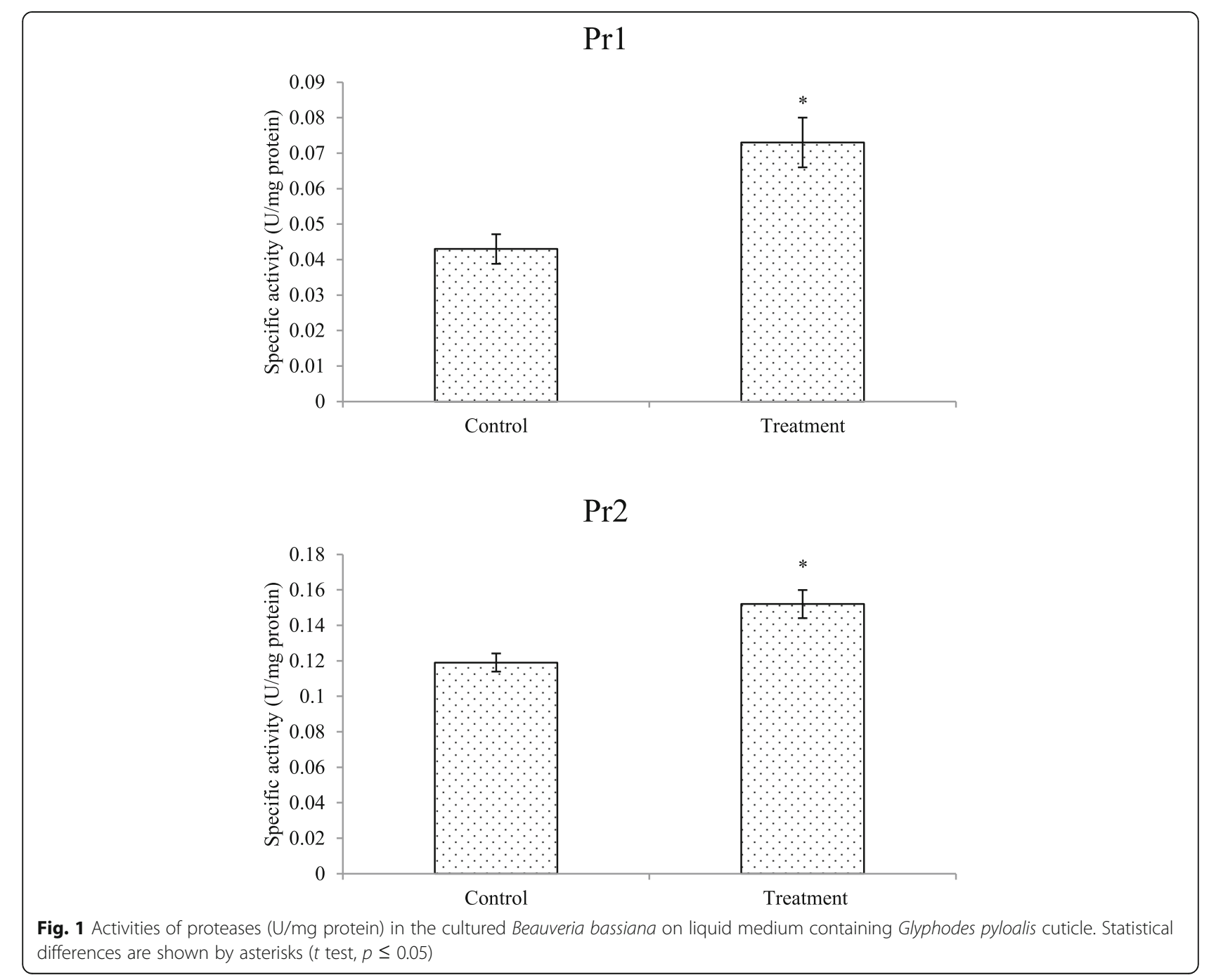




\section{Endochitinase}

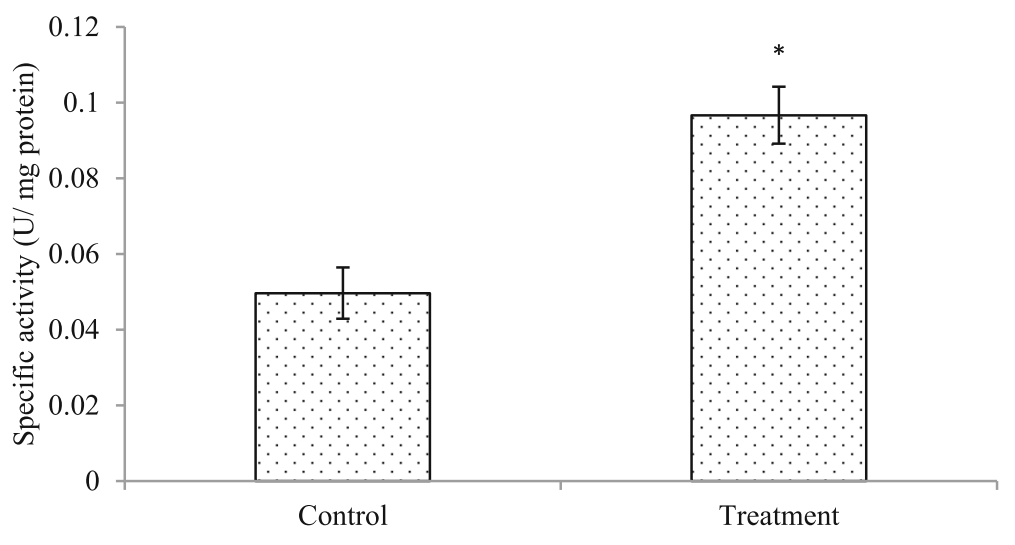

Exochitinase

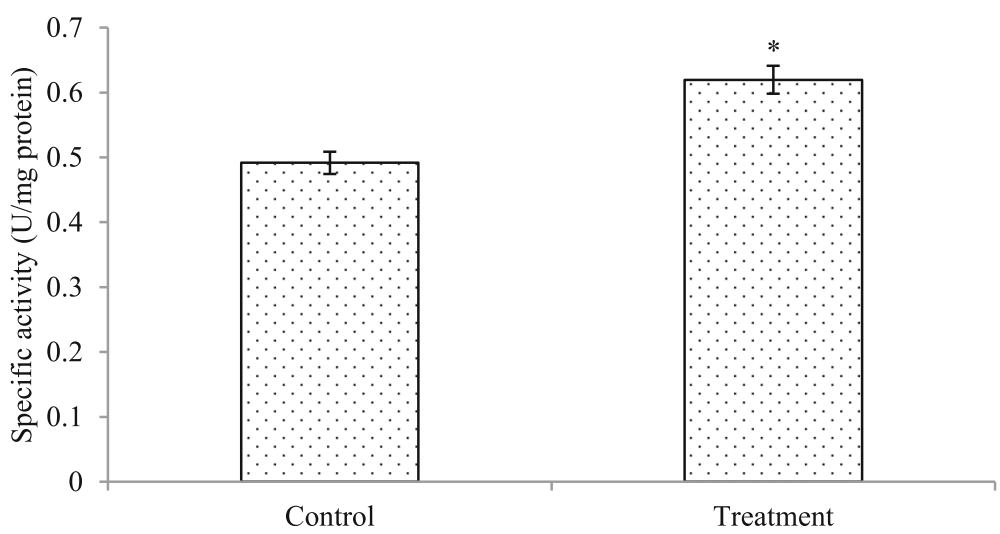

Fig. 2 Activities of chitinases (U/mg protein) in the cultured Beauveria bassiana on liquid medium containing Glyphodes pyloalis cuticle. Statistical differences are shown by asterisks ( $t$ test, $p \leq 0.05$ )

cellular immune responses of the larvae. Ramzi and Zibaee (2014) reported that two isolates of B. bassiana (BB1 and BB2) had a high virulence against Chilo suppressalis Walker (Lepidoptera: Crambidae) larvae compared to Metarhizium anisopliae Metchnikoff (Hypocreales: Clavicipitaceae), Isaria fumosoroseus Wize (Hypocreales: Clavicipitaceae), and Lecanicilium lecanii Zare \& Gams (Hypocreales: Cordycipitaceae). Wraight et al. (2010) demonstrated a high virulence of B. bassiana isolates against Plutella xylostella L. (Lepidoptera: Plutellidae), Helicoverpa zea Boddie (Lepidoptera: Noctuidae), Ostrinia nubilalis Hubner (Lepidoptera: Crambidae), Spodoptera frugiperda Smith (Lepidoptera: Noctuidae), Spodoptera exigua Fabricius (Lepidoptera: Noctuidae), Agrotis ipsilon Hufnagel (Lepidoptera: Noctuidae), Pieris rapae L. (Lepidoptera: Pieridae), and Trichoplusia ni Hubner (Lepidoptera: Noctuidae). Laznik et al. (2012) investigated the effects of Beauveria brongniartii Vuillemin and B. bassiana against June beetle, margined vine chafer, and garden chafer. The authors reported significant effects of the fungi on the total number of the white grubs in April and May once the population was higher than the economic threshold. Also, the highest virulence of B. bassiana was observed on the Duponchelia fovealis Zeller (Lepidoptera: Crambidae) larvae (Baja et al. 2020). B. bassiana (different isolates) are among the most virulent EPF against insects and it has shown a significant capability to be used as an efficient biocontrol agent in agro-ecosystems. Moreover, AM-118, the native isolate of B. bassiana in north of Iran, has shown a virulence against $C$. suppressalis and Pseudococcus viburni Signoret (Hemiptera: Pseudococcidae). Lesser mulberry is the third case of pests which is susceptible to the isolate, which implied on the pathogenic ability of AM-118 in a wide range of crop and orchard pests. This may be attributed to the isolate adaptability to the climate of northern Iran and host-associations which emboss virulence of AM-118 microbe. 


\section{Total hemocyte}
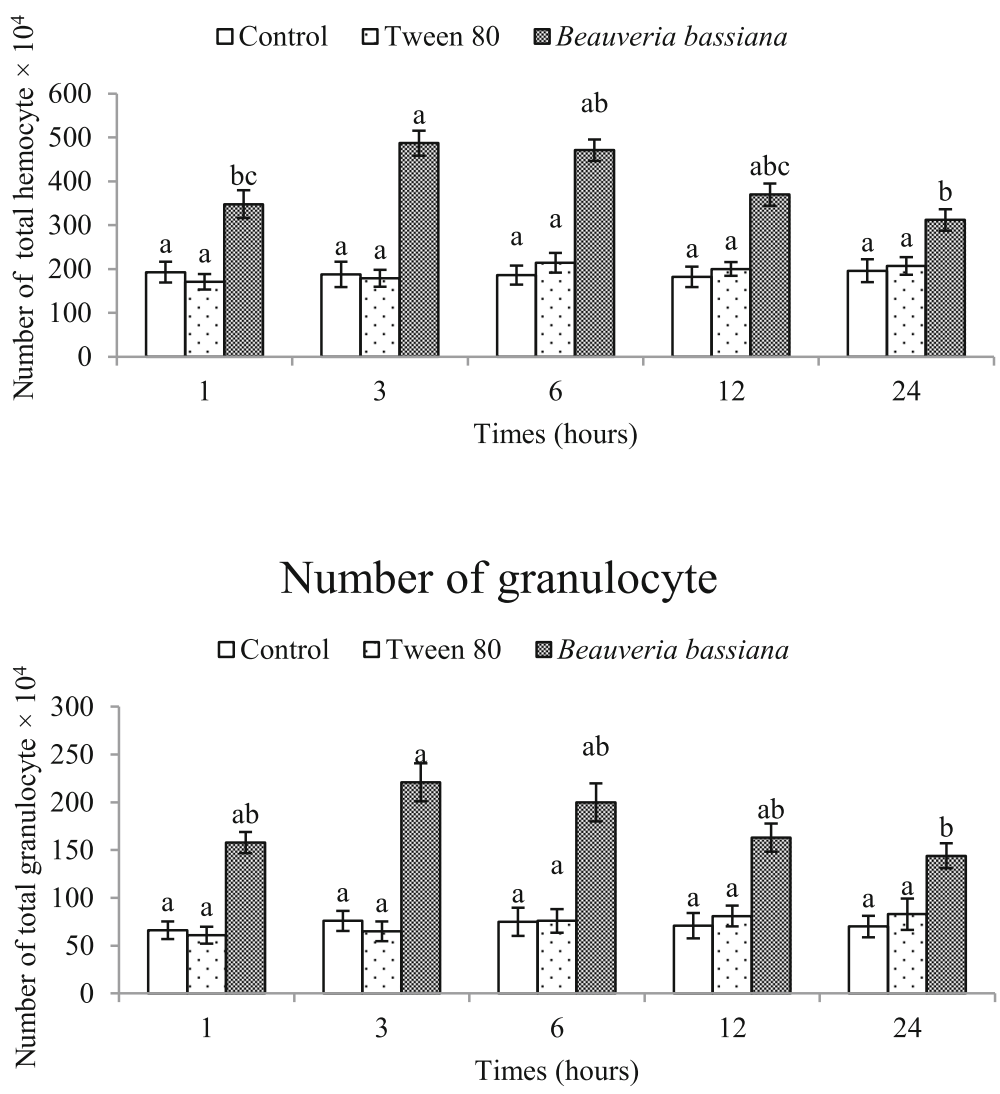

Number of plasmatocyte

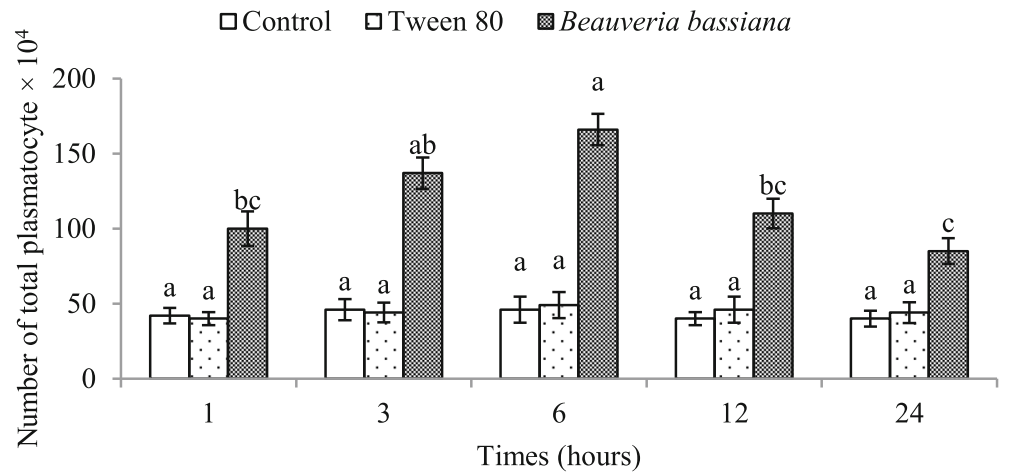

Fig. 3 Changes of hemocytes numbers in Glyphodes pyloalis larvae injected by $2.6 \times 10^{5} \mathrm{spore} / \mathrm{ml}$ of Beauveria bassiana (AM-118). Different letters indicate significant differences among treatments in time intervals $(p \leq 0.05)$

Once fungal conidium attached to the integument of insects, it generates a germ tube and penetrates by passing through cuticle, using extracellular enzymes and mechanical pressure. Proteases and chitinases are the necessary enzymes to facilitate fungal penetration through insect cuticle (Ramzi and Zibaee 2014). Subtilisin-like (Pr1) and trypsin-like (Pr2) are the 2 types of proteases important in pathogenic process of EPF. Pr1 catalyzes widely the cuticular protein of insects and is secreted in the initial steps of penetration, while Pr2 plays as a supplementary protease to accomplish protein degradation along with Pr1 (Dias et al. 2008). Chitinases speed up the hydrolysis of b- $(1,4)$-linked polymer of $N$ acetyl-D-glucosamine in insect cuticle although they play 


\section{Number of nodules}

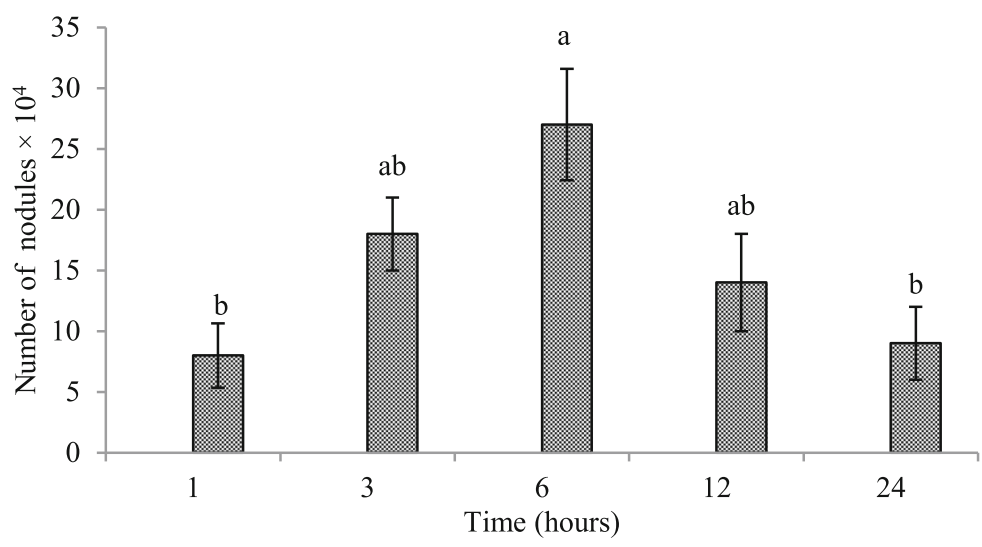

Phenoloxidase

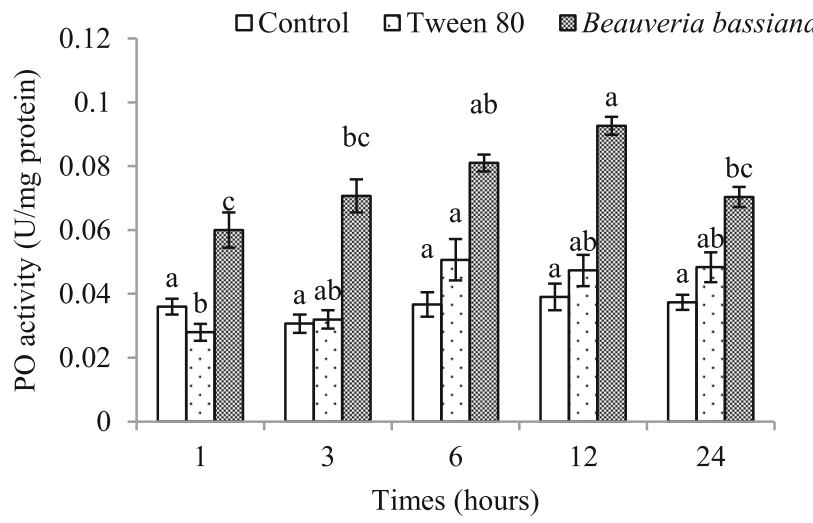

Fig. 4 Changes of nodules numbers and PO activity (U/mg protein) in Glyphodes pyloalis larval hemolymph after injection with $2.6 \times 10^{5}$ spore/ $\mathrm{ml}$ of Beauveria bassiana (AM-118). Different letters indicate significant differences among treatments in time intervals $(p \leq 0.05)$

other roles in development, nutrition, and morphogenesis of fungi (Tsigos and Bouriotis 1995). High activities of fungal enzymes in the presence of larval cuticle implies on better adaptations of these enzymes with integument composition of host rather than pure supplements in control media. In fact, there is a coevolution in hostmicrobe associations in which the EPF recruit the enzymatic isoforms to facilitate integument rupture and to enhance achieving of fungus to the haemocoel of host.

Microbial infections are generally lethal for insects, but several studies demonstrate that some physiological functions neutralize the damage of infectious injury (Gorman et al. 2007; Vengateswari et al. 2020). Immunity is important to protect insects against microbial agents. Immune responses of insects rely on circulating hemocytes such as prohemocyte, granulocyte, plasmatocyte, and oenocytoids (Russo et al. 2001; SchmidHempel 2005; Borges et al. 2008; Zibaee and Malagoli 2014). The hemocytes act through different functions including nodule formation, phagocytosis, and encapsulation to entrap and kill pathogens in the hemolymph (Borges et al. 2008). In the present study, the results demonstrated that injecting of Am-118 spores to $G$. pyloalis larvae led to increase of total and differentiated hemocyte counts than to tween 80 and control larvae. Similar findings were observed in case of number of nodules, which highlight the roles of circulating hemocytes in alleviating or removing deleterious effects of entomopathogenic infection. Similar studies demonstrated a direct correlation between EPF infection and number of differential hemocytes in insects. For example, Mirhaghparast et al. (2013) showed that injection of Spodoptera littoralis Boisduval (Lepidoptera: Noctuidae) larvae by $B$. bassiana and $M$. anisopliae increased the number of hemocytes and nodules. In another research, Zibaee and Malagoli (2014) reported that the number of hemocytes and nodules in C. suppressalis increased after injection with different EPF. 
Phenoloxidase (PO) is an important enzyme in immunity of insect, which has a key role in catalyzing hydroxylation of monophenols to diphenols and conversion of diphenols to quinones (Gorman et al. 2007). Then, quinones are converted to the melanin pigments. In insects, melanin is involved in wound healing, cuticle sclerotization, and defense reactions against pathogens, such as encapsulation and nodule formation (ZdybickaBarabas et al. 2014). In the present study, there is a correlation between number of hemocytes and $\mathrm{PO}$ activity because the highest PO activity was obtained after 6 post-injections, which it coincided with the hemocytes high numbers in the given time of post injection. Since $\mathrm{PO}$ is secreted and stored within hemocytes, increased PO activity may be attributed to the highest number of hemocytes after injection of fungi conidia. Several studies have been demonstrated an increase of hemocytes' numbers causes increase PO activity of insects (Catalán et al. 2012; Mirhaghparast et al. 2013; Zibaee and Malagoli 2014; Shamakhi et al. 2019).

\section{Conclusion}

The present study revealed detailed results on the function of a native $B$. bassiana isolate from the pathogen infection-host interaction perspective. Injection of AM118 led to mortality of G. pyloalis larvae by increased secretion of extracellular enzymes and affected insect host immunity. Increased knowledge on the physiological interplays among EPF and the insect host could provide new strategies for pest management.

\section{Abbreviations}

PDA: Potato Dextrose Agar; Pr1: Subtilisin-like; Pr2: Trypsin-like;

TCA: Trichloroacetic acid; DNS: Dinitrosalicylic acid; pNPg: $p$-Nitrophenyl-Nacetyl- $\beta$-D-glucosaminide; L-dopa: 3,4-Dihydroxyphenylalanine;

$\mathrm{Cl}$ : Confidence interval; PO: Phenoloxidase

\section{Acknowledgements}

Authors would like to thank the University of Guilan (Rasht, Iran) for supporting our research.

\section{Authors' contributions}

SAP: Investigation, methodology, formal analysis, writing; AZ: supervision, writing-review and editing; MGR: methodology; $\mathrm{HH}$ : writing-review and editing; MS: supervision, formal analysis, methodology. All authors have read and approved the manuscript.

\section{Funding}

The authors would like to thank the University of Guilan (Grant Number 516235) for financial support of the research.

\section{Availability of data and materials}

Not applicable.

Ethics approval and consent to participate

Not applicable.

\section{Consent for publication}

Not applicable.

\section{Competing interests}

The authors declare no competing interests.

\section{Author details}

${ }^{1}$ Department of Plant Protection, Faculty of Agricultural Sciences, University of Guilan, Box 41635-1314, Rasht, Iran. 'Iranian Research Institute of Plant

Protection, Agricultural Research, Education and Extension, Amol, Iran.

Received: 2 December 2020 Accepted: 12 February 2021

Published online: 19 February 2021

\section{References}

Azambuja P, Garcia ES, Ratcliffe NA (1991) Aspects of classification of hemiptera hemocytes from six triatomine species. Mem Inst Oswaldo Cruz 86:1-10. https://doi.org/10.1590/S0074-02761991000100002

Baja F, Poitevin CG, Araujo ES, Mirás-Avalos JM, Zawadneak MA, Pimentel IC (2020) Infection of Beauveria bassiana and Cordyceps javanica on different immature stages of Duponchelia fovealis Zeller (Lepidoptera: Crambidae). Crop Prot 138:105347. https://doi.org/10.1016/j.cropro.2020.105347

Borges AR, Santos PN, Furtado AF, Figueiredo RCB (2008) Phagocytosis of latex beads and bacteria by hemocytes of the triatomine bug Rhodnius prolixus (Hemiptera: Reduvidae). Micron 39:486-494. https://doi.org/10.1016/j.micron.2 007.01.007

Brownbridge M, Costa S, Jaronski ST (2001) Effects of in vitro passage of Beauveria bassiana on virulence to Bemisia argentifolii. J Invertebr Pathol 77: 280-283. https://doi.org/10.1006/jipa.2001.502

Catalán TP, Niemeyer HM, Kalergis AM, Bozinovic F (2012) Interplay between behavioral thermoregulation and immune response in mealworms. J Insect Physiol 58:1450-1455. https://doi.org/10.1016/j.jinsphys.2012.08.011

Dias BA, Neves PMOJ, Furlaneto-Maia L, Furlaneto MC (2008) Cuticaledegrading proteases produced by the entomopathogenic fungus Beauveria bassiana in the presence of coffee berry borer cuticle. Braz J Microbiol 39:301-306. https://doi.org/10.1590/S1517-83822008000200019

Gorman MJ, An C, Kanost MR (2007) Characterization of tyrosine hydroxylase from Manduca sexta. Insect Biochem Mol Biol 37:1327-1337. https://doi.org/1 0.1016/j.ibmb.2007.08.006

Khosravi R, Jalali Sendi J (2010) Biology and demography of Glyphodes pyloalis Walker (Lepidoptera: Pyralidae) on mulberry. J Asia Pac Entomol 13:273-276. https://doi.org/10.1016/j.aspen.2010.04.005

Laznik Z, Vidrih M, Trdan S (2012) The effect of different entomopathogens on white grubs (Coleoptera: Scarabaeidae) in an organic hay-producing grassland. Arch Biol Sci 64(4):1235-1246

Lowry OH, Rosenbrough NJ, Farr LL, Randall RJ (1951) Protein measurement with the Folin phenol reagent. J Biol Chem 19:265-275

Miller GL (1959) Use of dinitrosalicylic acid reagent for determination of reducing sugar. Anal Chem 31:426-428. https://doi.org/10.1021/ac60147a030

Mirhaghparast SK, Zibaee A, Hajizadeh J (2013) Effects of Beauveria bassiana and Metarhizium anisopliae on cellular immunity and intermediary metabolism of Spodoptera littoralis Boisduval (Lepidoptera: Noctuidae). Invertebr Surviv J 10: 110-119

Ramzi S, Zibaee A (2014) Biochemical properties of different entomopathogenic fungi and their virulence against Chilo suppressalis (Lepidoptera: Crambidae) larvae. Biocon Sci Technol 24:597-610. https://doi.org/10.1080/09583157.2 014.883360

Russo J, Brehelin M, Carton Y (2001) Haemocyte changes in resistant and susceptible strains of $D$. melanogaster caused by virulent and avirulent strains of the parasitic wasp Leptopilina boulardi. J Insect Physiol 47:167-172. https:// doi.org/10.1016/S0022-1910(00)00102-5

Schmid-Hempel P (2005) Evolutionary ecology of insect immune defenses. Annu Rev Entomol 50:529-551. https://doi.org/10.1146/annurev.ento.50. 071803.130420

Shamakhi L, Zibaee A, Karimi-Malati A, Hoda H (2019) Effect of thermal stress on the immune responses of Chilo suppressalis walker (Lepidoptera: Crambidae) to Beauveria bassiana. J Therm Biol 84:136-145. https://doi.org/10.1016/j. jtherbio.2019.07.006

Tsigos I, Bouriotis V (1995) Purification and characterization of chitin deacetylase from Colletotrichum lindemuthianum. J Biol Chem 270:26286-26291. https:// doi.org/10.1074/jbc.270.44.26286

Vengateswari G, Arunthirumeni M, Shivakumar MS (2020) Effect of food plants on Spodoptera litura (Lepidoptera: Noctuidae) larvae immune and antioxidant properties in response to Bacillus thuringiensis infection. Toxicol Rep 7:14281437. https://doi.org/10.1016/j.toxrep.2020.10.005

Watanabe Y, Kurihara Y, Wang XY, Shimizu TJ (1988) Mulberry pyralid, Glyhodes pyloalis: habitual host of nonoccluded viruses pathogenic to the silkworm, 
Bombyx mori. J Invertebr Pathol 52:401-408. https://doi.org/10.1016/0022-2 011(88)90052-3

Wilson K, Thomas MB, Blanford S, Doggett M, Simpson SJ, Moore SL (2002) Coping with crowds: density-dependent disease resistance in desert locusts. Proc Natl Acad Sci U S A 99:5471-5475. https://doi.org/10.1073/ pnas.082461999

Wraight SP, Ramos ME, Avery PB, Jaronski ST, Vandenberg JD (2010) Comparative virulence of Beauveria bassiana isolates against lepidopteran pests of vegetable crops. J Invertebr Pathol 103:186-199. https://doi.org/10.1016/j.jip.2 010.01.001

Yazdani E, Sendi JJ, Aliakbar A, Senthil-Nathan S (2013) Effect of Lavandula angustifolia essential oil against lesser mulberry pyralid Glyphodes pyloalis Walker (Lep: Pyralidae) and identification of its major derivatives. Pestic Biochem Physiol 107:250-257. https://doi.org/10.1016/j.pestbp.2013.08.002

Zdybicka-Barabas A, Mak P, Jakubowicz T, Cytryńska M (2014) Lysozyme and defense peptides as suppressors of phenoloxidase activity in Galleria mellonella. Arch Insect Biochem Physiol 87:1-12. https://doi.org/10.1002/a rch. 21175

Zibaee A, Bandani AR (2009) Purification and characterization of the cuticledegrading protease produced by the entomopathogenic fungus, Beauveria bassiana in the presence of Sunn pest, Eurygaster integriceps (Hemiptera: Scutelleridae) cuticle. Biocontrol Sci Tech 19:797-808. https://doi. org/10.1080/09583150903132172

Zibaee A, Malagoli D (2014) Immune response of Chilo suppressalis Walker (Lepidoptera: Crambidae) larvae to different entomopathogenic fungi. Bull Entomol Res 104:155-163. https://doi.org/10.1017/S0007485313000588

\section{Publisher's Note}

Springer Nature remains neutral with regard to jurisdictional claims in published maps and institutional affiliations.

\section{Submit your manuscript to a SpringerOpen ${ }^{\circ}$ journal and benefit from:}

- Convenient online submission

- Rigorous peer review

- Open access: articles freely available online

- High visibility within the field

- Retaining the copyright to your article

Submit your next manuscript at $\boldsymbol{\nabla}$ springeropen.com 